\title{
Araztegi-lokatzak jasotako lurzoruaren analisi toxikologikoa zizare eta landareak erabiliz
}

\author{
(Toxicological analysis of soils poured with sewage sludges using \\ worms and plants)
}

\author{
Erik Urionabarrenetxea ${ }^{1}$, Nerea Garcia-Velasco ${ }^{1}$, Patxi Beraza ${ }^{2}$, \\ Marta Sánchez ${ }^{2}$, Urtzi Izagirre ${ }^{1}$, Beñat Zaldibar ${ }^{1}$, Manu Soto*1 $^{*}$ \\ ${ }^{1}$ Zelulen Biologia Ingurumen Toxikologian (ZBIT) ikerketa-taldea, Zoologia eta Animalia \\ Zelulen Biologia Saila, Zientzia eta Teknologia Fakultatea eta Plentziako Itsas Estazioa \\ (PiE-UPV/EHU), Euskal Herriko Unibertsitatea (UPV/EHU), Leioa, Bizkaia \\ ${ }^{2}$ GEYSER HPC S.A.U Iparragirre etorbidea 80, $1^{\circ}$ esk. 48940 Leioa (Bizkaia)
}

\begin{abstract}
LABURPENA: Urtetik urtera areagotzen diren giza populazioak eta jarduera industrialak zabortegi, isuri-puntu eta betetze guneen emendioa eragin du. Zabortegi horien artean, 48046-00181 kodearekin, «17-zabortegia» dago, Gernika-Lumon kokatua (4319'28,9'N 240'30,9'W.). Zabortegi horretan, Gernikako araztegiko arazketa-lokatzak isuri izan ziren ongarri gisa urteetan zehar; eta, horrela, Gernikako industrian sortutako hainbat kutsatzaile (metal astunak, PAHak, pestizidak, etab.) bertan lurperatu ziren. Isurketaren eraginez gehien kaltetutako espezieen artean, azpimarratzekoak dira landareak eta zizareak edo antzeko lurzoruko ornogabeak; batez ere, berorien eta lurzoru-matrizearen arteko kontaktu estuagatik. Testuinguru horretan, lan honen helburua da lokatz horien isurketak eragindako efektuen ebaluazio bat gauzatzea, lurzoruari beste erabilera bat emate aldera; eta, horretarako, zabalki ezagunak diren test estandarizatu eta biomarkatzaileak erabiliko dira: organismo (uraza eta zizare), denbora ( $3,7,28$ eta 56 egunera) eta konplexutasun biologiko desberdinetan (zelula-mailatik populazio-mailara arte). Besteak beste, OECD-204 (toxikotasun akutuaren testa), OECD-222 (ugalketa-testa) eta kaltzeina AM bideragarritasun-testak aplikatu ziren Eisenia fetida zizarean, paraleloki, Lactuca sativa landareetan ernetze- eta elongazio-testak gauzatu ziren heinean. Azterketa toxikologikoen ostean, kontrolarekiko desberdintasun esanguratsuak ikusi ziren: erauzitako zelomozito kantitatean, bideragarritasun zelularrean, ehunetan metatutako metal-kontzentrazioetan, hazkuntza-parametroetan (pisu-galeran) eta ugalketa-parametroetan, kutsatzaileek lurzoru biotan eragindako afekzioa berretsiz. L. sativa espeziarekin egindako frogetan, aldiz, ez zen desberdintasun nabarmenik preziatu talde esperimentalen artean.
\end{abstract}

HITZ GAKOAK: araztegi-lokatzak, metal astunak, ekotoxikologia, Eisenia fetida, Lactuca sativa, biomarkatzaileak, toxikotasun-proba estandarrak.

ABSTRACT: Increasing global population, along with a rising industrial activity and soil scarceness led to landfill, spill and filling point extension. Among this landfills, "Landfill 17" can be found with 48046-00181 code; located in Gernika-Lumo (4319'28,9"N $2^{\circ} 40^{\prime} 30,9^{\prime}$ 'W, Basque Country). There, sewage sludges coming from Gernika waste water treatment plant were poured with a hose with agricultural purposes; thus, many pollutants with industrial origin (heavy metals, PAHs and pesticides among others) ended up in the mentioned soils. Among the species mostly affected by the contamination, plants and earthworms must be highlighted due to their close relation with soil matrix; and therefore, soil pollution. In this context, the aim of this work is to evaluate the effects exerted by pollutants in the spilling in order to assess potential Landfill future uses; using for that widely known biomarkers and standardized tests in different organisms (lettuce and earthworms), exposure times (3, 7 , 28 and 56 days) and complexity levels (from cellular level to populational level) for that. Indeed, OECD-204 (acute toxicity test), OECD-222 (reproduction test) and calcein AM tests were applied in Eisenia fetida earthworms; while, germination and elongation tests were applied on Lactuca sativa plants. After carrying out ecotoxicological assays, significant differences respect to the control were observed in: extruded coelomocyte quantity, cell viability, tissue metal accumulations, growth (weight loss) parameters or reproductive parameters; proving pollutants affection upon soil biota. However, no significant differences were observed between experimental groups in those tests carried out with L. sativa.

KEYWORDS: sewage sludge, heavy metals, ecotoxicology, Eisenia fetida, Lactuca sativa, biomarkers, standard toxicity tests.

\footnotetext{
* Harremanetan jartzeko / Corresponding author: Manu Soto. Zoologia eta Animalia Zelulen Biologia Saila, Zientzia eta Teknologia Fakultatea eta Plentziako Itsas Estazioa (PiE-UPV/EHU). - manu.soto@ehu.eus - https://orcid.org/0000-0002-4541-8182

Nola aipatu / How to cite: Urionabarrenetxea, Erik; Garcia-Velasco, Nerea; Beraza, Patxi; Sánchez, Marta; Izagirre, Urtzi; Zaldibar, Beñat; Soto, Manu (2020). "Araztegi-lokatzak jasotako lurzoruaren analisi toxikologikoa zizare eta landareak erabiliz». Ekaia, 40, 2021, 135-155. (https://doi.org/10.1387/ekaia.21807).
}

Jasotze-data: 2020, ekainak 10; Onartze-data: 2020, abenduak 4.

ISSN 0214-9753 - elSSN 2444-3581 / (c) 2021 UPV/EHU

(†) $\odot$ Lan hau Creative Commons Aitortu-EzKomertziala-LanEratorririkGabe 4.0 Nazioartekoa lizentzia baten mende dago 
Erik Urionabarrenetxea, Nerea Garcia-Velasco, Patxi Beraza, Marta Sánchez, Urtzi Izagirre, Beñat Zaldibar, Manu Soto

\section{SARRERA}

Azken mendean nekazaritzan eta industrian izan diren aurrerakuntza zientifiko eta teknologikoek munduko biztanleria laukoiztea ahalbidetu dute [1]. Eztanda demografiko horrek, lurzoru erabilgarriaren eskasiarekin eta kultura kontsumista batekin batera, zabortegien, isuri-puntuen edota betetze-puntuen emendatzea eragin du. Euskal Autonomia Erkidegoko irailaren 30eko 165/2008 Dekretuan, lurzorua kutsa dezaketen jarduerak zein instalazioak izan dituzten lurzoruak inbentariatzen dituen hartan, $1.277 \mathrm{za}-$ bortegi daude. Inbentario horretan, 17-zabortegia agertzen da Gernika-Lumon. Egun zabortegia den lurzoruetan, hainbat hamarkadatan zehar, Gernika-Lumo araztegiko lokatzak bota ziren ongarri gisa, nekazaritza-jarduera bultzatu asmoz. Baina uztak elikatuko zituen materia organikoarekin batera, araztegiak garbitu ezin zitzakeen kutsatzaileak heldu ziren lurzoruetara. Izan ere, Gernika-Lumoko saneamendu-sistema unitarioa da; hots, ez ditu ur zuriak eta beltzak bereizten. Modu horretan, Gernikako industrian euriak garbitutako edo ilegalki kolektiboetara jaurtitako kutsatzaileek araztegian bukatu zuten; eta handik, lokatzen bitartez, lurzoruetan. Lokatzak 250 m-ra mahuka bitartez isurtzen zirela jakinda, Eusko Jaurlaritzak (GV/ EJ) 3,38 hektareako zabortegi aitortu zuen araztegiaren iparraldeko luresparrua; 17-zabortegia, alegia. Gaur egun, lur-esparru osoa (zabortegiari dagokiona) itxita mantentzen da; debekatuta dago bertan edozein aisialdi edo ekintza sozioekonomiko. Hala ere, Gernika-Lumoko Udalak zabortegiaren hegoaldean dagoen Urbietako kirolekua handitzea aurreikustena du, posible bada, zabortegiaren zati bat hartuz. Honako lan hau testuinguru horretan kokatzen da; 17-zabortegiko lurzoruen toxikotasunaren jarraipenean eta kontrolean. Horretarako, bioentseguak gauzatu dira Eisenia fetida zizarea bezalako organismo lurtarrekin eta Lactuca sativa landareekin.

Zizareak metalen metatzaile eraginkorrak dira, eta kutsaduraren aurrean erantzun sentikor eta neurgarria dute; horregatik, organismo behale horien erabilera oso zabaldua dago lurzoruen kutsadura ikertzeko. Zizareen artean, E. fetida/E. andrei espezieak dira erabilienak, mundu mailan onarturiko lurzoruen toxikotasun-test estandarretarako erabiltzen direlarik (OCDE 1984 [2]; ISO 2008 [3]). Kutsatzaileek zizareetan eragin dezaketen arrisku potentzialak ebaluatzeko, toxikotasun-test akutuak eta kronikoak daude. Toxikotasun-test akutuek konposatu batek denbora konkretu batean organismoen \% 50ean heriotza eragiteko dosia (LC50) ezartzea ahalbidetzen dute, arriskuen ebaluazioan edo konposatu kimikoen erregulazioan lagunduz [4]. Entsegu mota horien artean dago zizareak kutsatutako lurzoruarekin kontaktuan jartzean datzan Artificial soil testa [2]. Test hori animalien eta probatu beharreko substantzien arteko kontaktu dermikoan eta lurzorua ahoratzean oinarritzen da; animalien heriotza-tasaren eta pisu-galeraren bitartez ebaluatzen du toxikotasuna. Test horiek gauzatzeko, OECD edo LUFA bezalako lur estandarizatuak erabiltzen dira; horrela, herrialde 
ezberdinetako laborategietan emaitza berdintsuak lor daitezke, eta horrek konparaketak errazten ditu eta ezarritako toxikotasun-neurketen fidagarritasuna areagotzen du [5].

Toxikotasun kronikoa aztertzerakoan, garrantzi handiko faktorea da ugalketa $[4,6,7]$, populazioen dinamiketan daukan garrantziagatik. Horrela, hazkuntzan edo ugalketan gerta daitezkeen aldaketak elementu erabilgarriak izan daitezke populazio-mailako efektuak aurreikusteko [8]. Horien artean dugu OECD-222 [9] testa, ugalketaren gaineko agente kimiko ezberdinen eragina aztertzeko diseinatu zena. Entsegu horietan, ugalketaren efektuak zortzi asteko esposizioaren ondoren neurtzen dira, lurzoruan hazi diren zizareen oinordekotza zenbatuz. Entsegu horien bitartez, gainera, hainbat indikatzaile lor daitezke: ECx, LC0, LC50, LC100, LOEC, NOEC eta ugalketa-tasak, besteak beste.

Aipatutako entsegu estandarizatuez gain, azken urteotan biomarkatzaile sorta zabala garatu izan da zizareetan efektu subletalak behatzeko; eta, hartara, lurzoruaren osasun-egoera ebaluatzeko. Biomarkatzaileek konplexutasun biologiko maila ezberdinetan (organismo behatzaileetan) gertatzen diren aldaketen gaineko informazio baliagarria ematen dute. Azterketa kimiko orokorrek edo ehunetan metatutako kutsatzaile kantitateak ez bezala, biomarkatzaileek kutsatzaileek organismoetan eragiten duten inpaktu biologikoaren gaineko informazioa ematen dute [10-11]. Zizareen kasuan, euren zelula immuneetan (zelomozitoak) neurtu ohi dira biomarkatzaileak. Izan ere, zelomozitoek kutsatzaile-kontzentrazio baxuen aurrean azaldu duten erantzun goiztiarrek konplexutasun-maila altuagoetan (ehun, organismo) pairatutako kalteak aurreikustea ahalbidetzen dute [12-13]. Zelomozitoekin egindako in vitro testen barruan, ondo hedatutako teknika da kaltzeina AM bideragarritasun-testa; teknika sentikor eta arina da substantzia kimikoek eragin ditzaketen efektu subletalak hautemateko. Horren bitartez, substantzia kimikoek zelulen euste-ahalmenean (kaltzeinaren metatzean) daukaten eragina aztertzen da, potentzialki toxikoak diren kimikoek mintz zelular eta lisosomikoetan sortzen dituzten kalteak kuantifikatuz. Azken hamarkadetan, banakako elementuen $(\mathrm{Cr}, \mathrm{Ni}, \mathrm{Pb}, \mathrm{Cd}, \mathrm{Cu}$, kerosenoa, etab.), nahaste konplexuen (errefusak, pestizidak, metalak eta kutsatzaile organikoak) zein lurzoru naturalen (utzitako meategiak, zabortegi ilegalak, etab.) toxikotasuna aztertu izan da E. fetidan; horretarako, analisi kimikoak, test estandarizatuak eta biomarkatzaile ezberdinen konbinazioak erabili dira [14-17].

Gaur egun, badira kutsatzaile ezberdinen toxikotasuna zehazteko landare-prozesuetan oinarritzen diren ikerketak ere. OECDk (2003) [18] eta EPAk (1996) [19] urazekin gauzatutako bioentseguak gomendatzen dituzte; batez ere, kutsatzaileek sor dezaketen ingurumen-arriskua ebaluatzeko metodo sinple, bizkor eta sentikorrak direlako [20]. Urazak, metalak sustrai bitartez xurgatzeko eta sustrai zein kimuetan metatzeko duten ahalmen altuagatik, lurzoruaren osasuna ikertzeko erabiltzen dira [20]. Urazekin gauzatutako entsegu 
Erik Urionabarrenetxea, Nerea Garcia-Velasco, Patxi Beraza, Marta Sánchez, Urtzi Izagirre, Beñat Zaldibar, Manu Soto

fitotoxiko estandar erabilienen artean daude hazien ernetze- eta sustraien elongazio-testak. Lehenengoa epe laburreko testzat hartzen da; bost egunetan zehar $(120 \mathrm{~h})$ plantulen garapenean izaten diren efektu toxiko akutuak zehazten laguntzen du. Aldiz, biomasa begetala eta sustraien elongazioa balioztatzen dituzten epe luzeko entseguek (bi eta zortzi aste bitartekoak) efektu toxiko akutu zein kronikoak zehazten lagun dezakete [21].

Lan honen helburua da 17-zabortegian isuritako araztegi-lokatzek sortutako toxikotasunaren ebaluazioa egitea da; espezie ornogabe eta landareen gaineko efektu biologikoak hartu dira irizpidetzat. Aipatutako testen bitartez, lokatzen isuriak espezie ornogabeengan eragiten duen pisu-galera, heriotza, ugalketa-kalteak edo landare espezieetan eragindako ernagarritasun-kalteak zein sustrai-kalteak ebaluatzea bilatzen da. Horrek eragindako ingurumen-kalteen gaineko jakintzan sakontzea ahalbidetuko du, eta, bide batez, kutsatutako lurzoruaren kudeaketan lagunduko du.

\section{MATERIALAK ETA METODOAK}

\subsection{Esperimentaziorako organismoak}

\subsubsection{Zizareak: Eisenia fetida}

Eisenia fetida espezieko zizareak Lombricor SCA (Kordoba) enpresan erosi ziren. Zizareak tenperatura $\left(19^{\circ} \mathrm{C}\right)$ eta hezetasun konstantean $(\% 60)$ mantendu ziren stock gisa, astero zaldi-gorotzekin elikatuz. Esperimenturako, zizare osasuntsu, klitelodun (heldu) eta tamaina antzekodunak (300-600 mg pisu hezea) erabili ziren.

\subsubsection{Uraza: Lactuca sativa}

Hazien ernetze- eta sustraien elongazio-testetarako, L. sativa haziak erabili ziren. Haziak tenperatura konstantean $\left(5^{\circ} \mathrm{C}\right)$ eta iluntasun-baldintzetan mantendu ziren, \% 10eko hezetasuna gainditzen ez zuten hermetikoki itxitako paketeetan. Esperimenturako, irregulartasunik gabeko haziak aukeratu ziren.

Ernetze-testean haziak erabili baino lehen, ernagarritasun-azterketak egin ziren uraza-stockaren \% 75eko ernagarritasun minimo bat bermatzeko.

\subsection{Lurzoruen egokitzapena}

17-zabortegiko lurzoruetan ( $\left.43^{\circ} 322434 \mathrm{~N},-2^{\circ} 675425 \mathrm{~W}\right), 20$ puntu ezberdinetako lur-laginak hartu ziren beren analisi kimiko eta fisikokimikoa egiteko. Proposatutako testak gauzatzeko, hartutako 20 laginetatik, MAN-7, MAN-14 eta MAN-17 puntuetako lurrak aukeratu ziren beren $\mathrm{Pb}, \mathrm{Ni}, \mathrm{Cd}$ eta $\mathrm{Cr}$ kontzentrazioak irizpidetzat hartuz, kutsatzaile horietarako Eusko Jaurlaritzak markatutako mugak gainditu zirelako. Lurzoru horiek behin lehortuta, bakoitza bere 
zelai-kapazitatearen \% 60ra hezetu zen 48 orduz, eta tenperatura- $\left(19^{\circ} \mathrm{C}\right)$ eta hezetasun-baldintza konstanteetan egonkortu zen. Erreferentzia gisa, LUFA 2.3 (Speyer, GER) lurzoru natural eta estandarrak erabili ziren.

1. taula. Aztertutako lurzoruen (MAN-7, MAN-14 eta MAN-17) materia organiko, pH kadmio, kromo, nikel eta berun kontzentrazioak. Pisu lehorra (PL adierazita).

\begin{tabular}{|c|cccc|}
\hline & LUFA 2.3 & MAN-17 & MAN-14 & MAN-7 \\
\hline Materia organikoa (LOI) \% P.L. & \pm 1 & 6,2 & 11 & 19 \\
pHa & 6,81 & 7,42 & 6,28 & 7,30 \\
Kadmioa (Cd) $\mathrm{mg} \mathrm{kg}^{-1}$ P.L. & LOD & 0,33 & 8,7 & 26 \\
Kromoa (Cr) $\mathrm{mg} \mathrm{kg}^{-1}$ P.L. & LOD & 41 & 190 & 400 \\
Nikela (Ni) $\mathrm{mg} \mathrm{kg}^{-1}$ P.L. & LOD & 32 & 56 & 120 \\
Beruna (Pb) $\mathrm{mg} \mathrm{kg}^{-1}$ P.L. & <LOD & 27 & 96 & 170 \\
\hline
\end{tabular}

\subsection{Lixibiatuen prestaketa}

Lurzoru kutsatuen lixibiatuak prestatzeko, Espainiako legislazioak ezarritako (BOE, 2005 516/id) DIN 38414-S4 (Deutsches Institut fur Normung, 1984 480/id) estandar alemana jarraitu zen. Horretarako, 10 g lurzoru (pisu lehorra) $100 \mathrm{~mL}$ ur distilaturekin nahastu, eta 24 orduz irabiatu zen girotenperaturan. Prozesu hori (LUFA 2.3), MAN-7, MAN-14 eta MAN-17 kontrol-taldeetan egin zen. Prestatutako lixibiatuak kimikoki analizatu ziren, eta $L$. Sativa hazien ernetze- zein sustraien elongazio-testetan erabili.

\subsection{Lactuca sativa hazien esposizioa kutsatutako lurzoruetan}

\subsubsection{Lactuca sativa hazien ernetze-testa}

Petri kutxetan, 15 g hare eta 15 L. sativa hazi jarri ziren, eta, jarraian, MAN-7, MAN-14 eta MAN-17 lurretatik eratorritako lixibiatuekin hezetu ( $3 \mathrm{ml}, \mathrm{n}=3$ ). Era berean, testa bermatzeko intentzioarekin, kontrol positibo talde bat gehitu zen, zeinetan haziak parke publikoetarako muga-kontzentrazioen pean $\left(25 \mathrm{mg} \mathrm{kg}^{-1} \mathrm{Cd}, 400 \mathrm{mg} \mathrm{kg}^{-1} \mathrm{Cr}, 500 \mathrm{mg} \mathrm{kg}^{-1} \mathrm{Ni}\right.$ eta $450 \mathrm{mg} \mathrm{kg}^{-1} \mathrm{~Pb}$ ) hazi baitziren $(n=3)$. Hazkuntza iluntasun, tenperatura $\left(20^{\circ} \mathrm{C}\right)$ eta hezetasun konstantepean garatu zen, 48 eta 168 ordutara ernaltzea aztertzeko.

\subsubsection{Sustraien elongazio-testa}

25 hazi 48 orduz iluntasun-baldintzetan eta kutsatzailerik gabe aurreernetu ondoren, sustraien luzera neurtu zen eta hoziak lixibiatuen pean jarri ziren. Kontrolen kasuan, ordea, ura erabili zen. Zortzi orduz hezetasun, tenperatura eta iluntasun-baldintza konstantepean haziak mantenduta gero, 
Erik Urionabarrenetxea, Nerea Garcia-Velasco, Patxi Beraza, Marta Sánchez, Urtzi Izagirre, Beñat Zaldibar, Manu Soto

sustraien hazkuntza neurtu zen. Analisi kimikoak gauzatze aldera, landareak labean lehortu ziren $36^{\circ} \mathrm{C}$-tan 72 orduz, ondoren eho eta digeritzeko $\left(\mathrm{HNO}_{3}\right)$. Analisi kimiko guztiak masen espektrometria akoplamendu induktiboko plasmarekin (ICP-MS) gauzatu ziren.

\subsection{Eisenia fetida zizareen esposizioa kutsatutako lurzoruetan}

\subsubsection{Toxikotasun akutuaren testa}

Esperimentaziorako aukeratutako MAN-7, MAN-14 eta MAN-17 talde bakoitzetik $750 \mathrm{~g}$ lurzoru kristalezko ontzietan jarri ziren, eta ontzi horietan, pisatutako hamar zizare sartu ziren (hiru erreplika). Ontziak tenperatura-baldintza optimopean $\left(19^{\circ} \mathrm{C}\right)$ eta argipean mantendu ziren, zizare-lurzoru arteko kontaktu etengabea bermatuz. Hiru egunera, zizareen pisu-galera eta hilkortasuna neurtzeaz gain, Kaltzeina AM bideragarritasun-testa (ikus 2.6.2) egin zen zelomozitoetan. Kontrol-taldeak LUFA 2.3 lurzoru estandarrean mantendu ziren esperimentu-baldintza berdinetan.

\subsubsection{Eisenia fetida zizareen ugalketa testa (OECD-222, 2004)}

$500 \mathrm{~g}$ kontrol, MAN-7, MAN-14 eta MAN-17 lur kristalezko ontzietan jarri ziren, eta horietara, 0,3-0,6 g bitarteko hamar zizare sartu ziren (lau erreplika). Esperimentazio-ontziak $19^{\circ} \mathrm{C}$-ko tenperatura konstantepean eta argitasun-iluntasun (16:8h) ziklopean mantendu ziren 56 egunez. Lehenbiziko 28 egunetan, $5 \mathrm{~g}$ zaldi-gorotz gehitu zitzaizkien astero, materia organikoaren ekarpen gisa; hezetasun-mailaren kontrola, aldiz, astero egin zen esperimentu osoan zehar. Behin 28 egun igarota, zizare helduak lurzoruetatik atera, balantza analitikoan pisatu eta analisi kimikoak egiteko erabili ziren; lurrean, arrautzak eta jubenilak utzi ziren, lehenago aipatutako baldintza berdinetan. Esperimentuaren 56. egunean, jubenilak kontatu eta jubenilen biomasa pisatu zen.

Esperimentazio-erreplika bakoitzeko, bost zizare erabili ziren analisi kimikoak egiteko. Behin zizareen liseri-traktua garbituta, labean lehortu ziren $120^{\circ} \mathrm{C}$-ra 48 orduz. Behin lehortuta, zizareen pisu lehorra neurtu eta $\mathrm{HNO}_{3-}$ arekin (Tracepur ${ }^{\circledR}, \%$ 69, 1M) estali ziren, digestioa burutu zedin; ondoren, disoluzio azidoak plaka bero batean jarri ziren lurrundu arte. Azkenik, $6 \mathrm{~mL} \mathrm{HNO}_{3} 0,01 \mathrm{M}$ gehitu zitzaizkien, neurketak burutu bitartean laginak $4^{\circ} \mathrm{C}$-tan mantenduz.

\subsection{Zelulen bideragarritasun-testak kutsatutako lurzoruetan izandako zizareen zelomozitoekin}

\subsubsection{Zelulen erauzketa eta kontaketa}

Hiru egunez MAN-7, MAN-14 eta MAN-17 lurpean izandako zizareak erauzketa-soluzioan (1 mL PBS \% 0,02 EDTA/zizare) sartu, eta 9 V-ko ko- 
rronte elektrikoa aplikatu zitzaien poro dortsaletatik zelomozitoak erauzteko (Irizar et al., 2014a). Lortutako zelulen soluzioa zentrifugazio-hodietan jaso zen, eta, jarraian, 530 g-tan eta tenperatura konstantean $\left(10^{\circ} \mathrm{C}\right) 10$ minutuz zentrifugatu. Behin prezipitatua lortuta, garbiketak burutu ziren PBS eta antibiotikodun (Saline phosphate buffer, $\mathrm{pH}$ 7.0-7.2) soluzio batekin esekiduran utziz. Jarraian, zelulak hemozitometroan zenbatu ziren, talde bakoitzeko zelula-dentsitatearen balioa lortze aldera; eta, ondoren, talde esperimental guztiak $1 \cdot 10^{6}$ zelula $/ \mathrm{mL}$ kontzentraziora eraman ziren. Soluzio zelularrak $96 \mathrm{pu}-$ tzuko mikroplaketan gehitu (200.000 zelula/putzuko), eta testak egin orduko, 30 minutuz egonkortzen utzi ziren $18^{\circ} \mathrm{C}$-tan, zelulen atxikitzea bermatzeko.

\subsubsection{Kaltzeina AM bideragarritasun-testa}

Plakak zentrifugatu $\left(1500 \mathrm{rpm}, 5 \mathrm{~min}, 10^{\circ} \mathrm{C}\right)$ ostean, gainjariakina kendu eta zelulak 40 minutuz 2.5 M Kaltzeina AMrekin inkubatu ziren $(\mathrm{n}=3,100 \mu \mathrm{L}$ putzuko). Tratamendu guztietan, $100 \mu \mathrm{L}$ PBS $(\mathrm{n}=3)$ gehitu ziren kontrol tekniko gisa, garbiketa-prozesuetan zehar taldeen arteko zelula-galera berdintsu bat bermatu eta zelulen autofloreszentzia balioetsi ahal izateko. Zelomozitoak birritan garbitu ostean (zentrifugatu, gainjariakina kendu eta $100 \mu \mathrm{L}$ PBS gehitu), fluoreszentzia-plakentzako FLx fluorimetroan neurtu ziren: $490 \mathrm{~nm}$-ko uhin-luzeran kitzikapenerako eta $520 \mathrm{~nm}$-tan emisiorako.

\subsection{Analisi estatistikoa}

Lortutako emaitzak SPSS softwarearen 22. bertsioan aztertu ziren. Datuen normaltasuna Kolmogorov-Smirnov eta Shapiro-Wilk testen bitartez frogatu zen. Distribuzio normala erakutsi zuten parametroak norabide bakarreko bariantza-analisi bidez ikertu ziren. Kontrolaren eta kutsatutako laginen arteko desberdintasun esanguratsu posibleak, ordea, Dunnet $(\mathrm{p}<0,05)$ post-hoc testaren bitartez analizatu ziren. Gainera, laginen arteko desberdintasunak Tukey testaren bitartez aztertu ziren. Aldiz, emaitza ez-parametrikoak Kruskal-Wallis testaren bitartez prozesatu ziren.

\section{EMAITZAK}

\subsection{Analisi fisikokimikoak}

\subsubsection{Lixibiatuen metal-determinazioa}

Lurzoru ezberdinetatik eskuratutako lixibiatuen artean metal-maila ezberdinak kuantifikatu ziren. MAN-14 lixibiatuak erakutsi zituen metal astunen kontzentrazio altuenak; aitzitik, metal astunen kontzentrazio baxuenak MAN-17 taldean neurtu ziren. 
2. taula. Aztertutako lurretako lixibiatuetan determinatutako $\mathrm{Cr}, \mathrm{Ni}$, $\mathrm{Cd}$ eta $\mathrm{Pb}$ kontzentrazioak $(\mu \mathrm{g} / \mathrm{L})$. *Kontrol-taldean lixibiatutako metalen kontzentrazioak detekzio-mugen azpitik neurtu ziren $(<\mathrm{LOD})$.

\begin{tabular}{|c|cccc|}
\hline & Kontrola & MAN-17 & MAN-14 & MAN-7 \\
\hline $\mathrm{Cr}$ & $<$ LOD & 4,7 & 31,5 & 12,6 \\
$\mathrm{Ni}$ & $<\mathrm{LOD}$ & 4 & 17,7 & 2,9 \\
$\mathrm{Cd}$ & $<\mathrm{LOD}$ & 0,5 & 2 & 1 \\
$\mathrm{~Pb}$ & $<\mathrm{LOD}$ & 2,7 & 12,4 & 5,8 \\
\hline
\end{tabular}

\subsection{Analisi toxikologikoak}

\subsubsection{Lactuca sativarekin egindako probak}

\subsubsection{Lactuca sativa hazien ernetze-testa}

Hiru egunetara neurtutako ernetzeek balio berdintsuak erakutsi zituzten bai aztertutako lurretan eta baita kontroletan ere. Ernetze-balio baxuenak MAN-14 and MAN-7 taldeetan kuantifikatu ziren, \% 66ko eta \% 70eko ernetze-portzentajeekin.

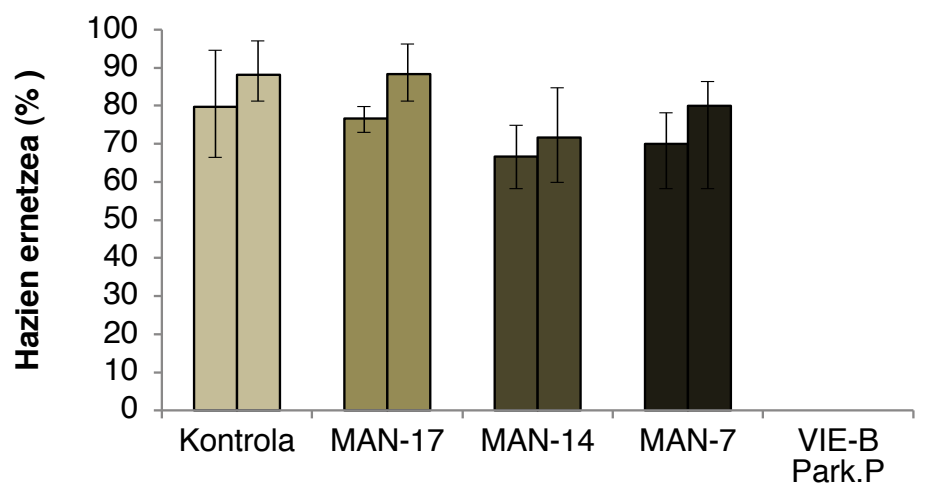

2. irudia. Lactuca sativa hazien ernetze-portzentajeak, $20^{\circ} \mathrm{C}$-ra, hiru (1.go zutabea) eta zazpi (2. zutabea) egunez lurzoruetatik erauzitako lixibiatuen pean izan ondoren. ${ }^{*}$ Ez zen ernalkuntzarik gertatu (\% 0).

Zazpigarren egunean hirugarren egunean antzemandako joera beretsuak ikusi ziren (2. irudia); hots, ez zen desberdintasun esanguratsurik aurkitu talde ezberdinen artean. MAN-14 eta MAN-7 lurretara esposatutako hazietan ernetze baxuagoak ikusi ziren; MAN-14a izan zen ernetze-portzentaje baxuena erakutsi zuen taldea. Ernalkuntza altuenak kontrol-taldean (\% 88) eta MAN-17 lurretara esposaturiko hazietan aurkitu ziren. 
Bestalde, parke publikoetarako limiteetan oinarritutako kontrol positiboan ez zen hazirik ernaldu.

\subsubsection{Sustraien elongazio-testa}

Bi egunetako esposizioaren ondoren, ez zen sustraien elongazioan ezberdintasun esanguratsurik aurkitu taldeen artean. Balio altuenak MAN-14 taldean ikusi ziren $(0,39 \mathrm{~mm}$, batez beste); eta baxuenak, berriz, MAN-7 taldean $(0,15 \mathrm{~mm}$, batez beste) .

\subsubsection{Urazen analisi kimikoa}

Sustraiak bi egunez lixibiatuen pean izan ondoren, landareen analisi kimikoak metal-metatze joera ezberdinak erakutsi zituen talde esperimental desberdinetan.

3. taula. $\mathrm{Cr}, \mathrm{Ni}, \mathrm{Cd}$ eta $\mathrm{Pb}$ kontzentrazioak Lactuca sativa ehunetan $(\mu \mathrm{g} \mathrm{Cd} / \mathrm{g}$ uraza), sustraiak bi egunez kutsatutako lurzoruetatik erauzitako lixibiatuetara esposatu ondoren. *dl adierazi dira detekzio-mugen azpitik (ICP-MS) zeuden kasuak.

\begin{tabular}{|c|cccc|}
\hline & Kontrola & MAN-17 & MAN-14 & MAN-7 \\
\hline $\mathrm{Cr}$ & $<$ LOD & $<$ LOD & $<$ LOD & 0,26 \\
$\mathrm{Ni}$ & $<\mathrm{LOD}$ & 4,64 & 3,29 & 8,79 \\
$\mathrm{Cd}$ & $<\mathrm{LOD}$ & 0,08 & 0,12 & 0,16 \\
$\mathrm{~Pb}$ & $<\mathrm{LOD}$ & 3,56 & 3,9 & 13,89 \\
\hline
\end{tabular}

Orokorrean, ez zen $\mathrm{Cd}$ eta $\mathrm{Cr}$ metaketa handirik ikusi aztertutako hiru talde esperimentaletan. $\mathrm{Pb}$ eta $\mathrm{Ni}$, aldiz, kantitate altuetan metatu ziren. MAN-7 taldea izan zen metalaren balio altuenak erakutsi zituen taldea; hala ere, ez zen desberdintasun esanguratsurik aurkitu talde esperimentalen artean.

\subsection{Esperimentuak zizareekin}

\subsubsection{Toxikotasun akutuaren testa}

\subsubsection{Pisu-galera}

Hiru egunez esposatutako zizareen pisu-galerak ez zuen inolako patroirik erakutsi esposizio taldeen artean. Pisu-galera altuenak MAN-17 eta MAN-7 taldeetan antzeman ziren; pisuaren \% 8,01 eta \% 9,6 galdu zuten, hurrenez hurren. Aldiz, pisu-galera txikiena MAN-14 taldeko organismoek pairatu zuten $(\% 7,39)$ 


\subsubsection{Erauzitako zelomozito kantitatea}

Hiru eguneko esposizioa pasatuta, zelula gutxiago erauzi ziren kutsatutako lurretan mantendutako zizareetatik.
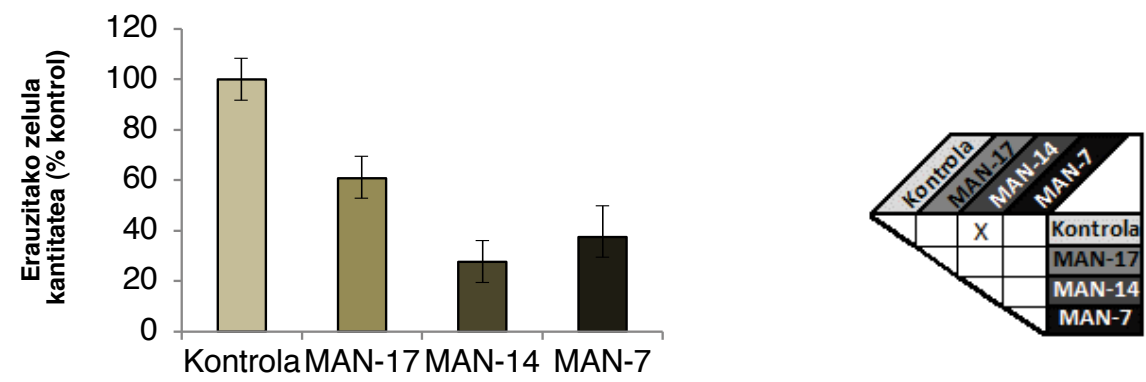

5. irudia. Eisenia fetida zizareetatik erauzitako zelula-portzentajeak (kontrolarekiko normalizatua; \%), hiru egunez kutsatutako lurzorupean izan ostean. Desberdintasun esanguratsuak $\mathrm{X}$ batekin adierazi dira eskuineko matrizean.

Erauzitako zelula-kontzentrazio baxuena MAN-14 lurzorura esposatutako organismoetan antzeman zen; horietan, kontrolean baino \% 73 zelula gutxiago kuantifikatu ziren (5. irudia). MAN-17 eta MAN-7 lurzoruetan, kontrolean zenbatutako zelulen \% 60a eta \% 37a kuantifikatu ziren, besteak beste. Kontrol-taldea izan zen erauzitako zelula kantitate altuena erakutsi zuen taldea.

\subsubsection{Kaltzeina AM bideragarritasun-testa}

Hiru egunez kutsatutako lurzoruetan izandako zizareen zelomozitoek kaltzeina gutxiago metatzeko joera erakutsi zuten kontrolekin alderatuz; hala nola, kontrol-taldean zeudenak baino \% 53-54 gutxiago (6. irudia).
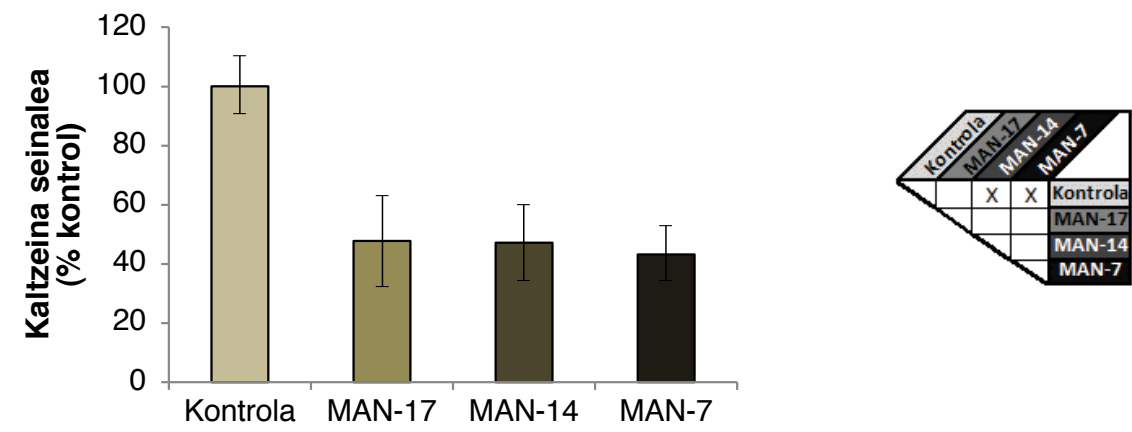

6. irudia. Kaltzeina AM bideragarritasun-testean lortutako seinalea (kontrolarekiko normalizatua; \%), zizareak hiru egunez kutsatutako lurzorupean izan ostean. Desberdintasun esanguratsuak $\mathrm{X}$ batekin adierazi dira eskuineko matrizean . 


\subsubsection{Eisenia fetida zizareen ugalketa-testa (OECD-222, 2004)}

\subsubsection{Zizareen analisi kimikoa}

Ugalketa-testaren lehen 28 egunak pasatu ostean, analisi kimikoek metal-metaketarako joera ezberdinak erakutsi zituzten talde ezberdinen artean.

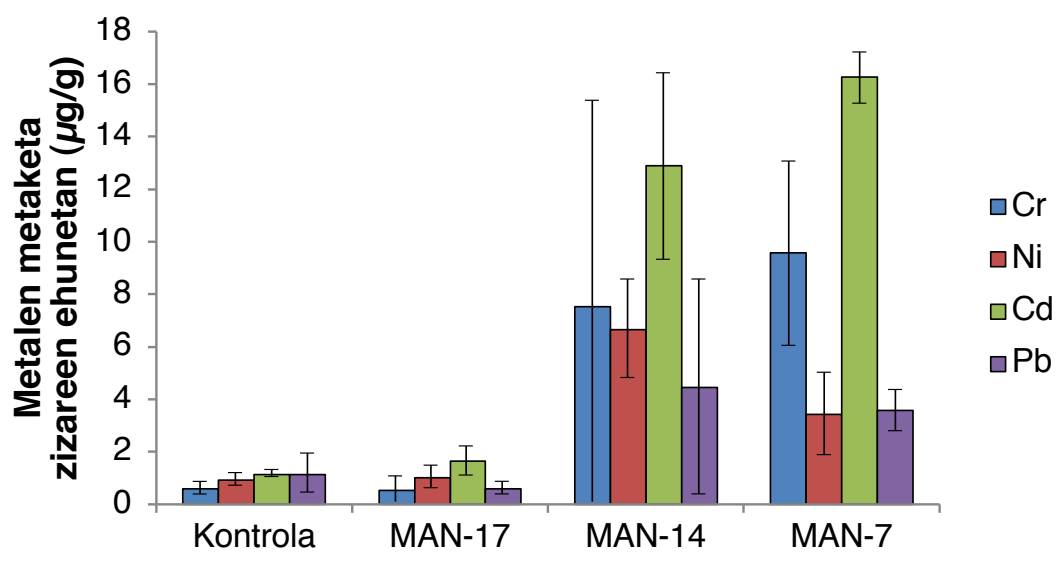

7. irudia. $\mathrm{Cr}, \mathrm{Ni}, \mathrm{Cd}$ eta $\mathrm{Pb}(\mu \mathrm{g} \mathrm{Cd} / \mathrm{g}$ zizare) kontzentrazioak Eisenia fetida ehunetan, horiek 28 egunez kutsatutako lurzorupean izan ondoren.

MAN-7 eta MAN-14 taldeek gorakada erakutsi zuten metal-metaketetan; MAN-17 taldeko zizareek, berriz, inolako metaketa esanguratsurik ez zuten erakutsi. Talde esperimentalak estatistikoki konparatuz, MAN-17ak ez zuen kontrolarekiko desberdintasunik erakutsi; MAN-17ak eta kontrol-taldeak baino $\mathrm{Cd}$ eta $\mathrm{Ni}$ nabarmen gehiago erakutsi zuen MAN-14ak. MAN-7 taldeak, berriz, neurtutako metal guztietan MAN-17ak eta kontrolak baino balio esanguratsuki altuagoak erakutsi zituen.

\subsubsection{Pisu-galera}

Ugalketa-testaren lehen 28 egunak igaro ondoren, galera altuenak kontrol-taldeetan gertatu ziren; jarraian, oso hurbil, MAN-17 esposizio-taldea zegoen (kontrolak baino \% 0,75 gutxiago). Aitzitik, pisu-galera baxuenak MAN-7 taldean antzeman ziren, non hazitako organismoek kontrolek (LUFA 2.3 lurzorua) galdutako pisuaren erdia baino gutxiago galdu baitzuten (kontrolek galdutakoaren \% 47). 

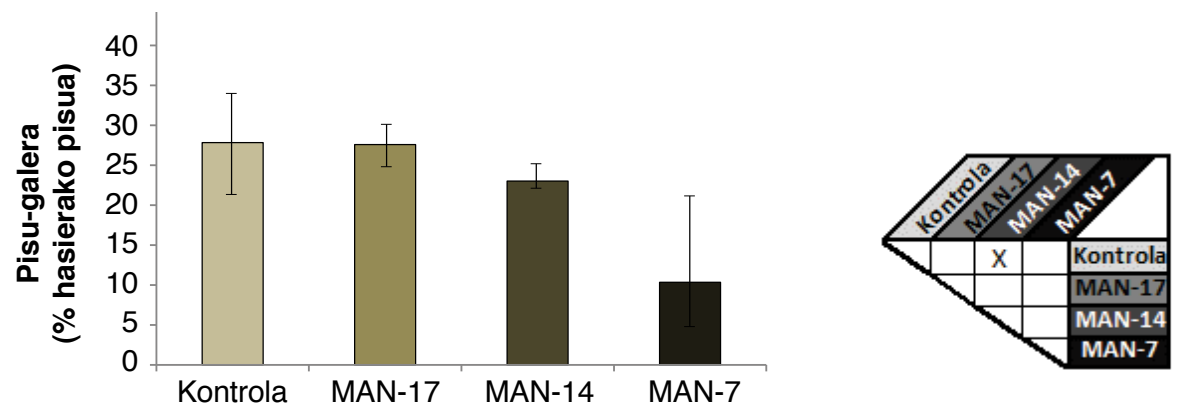

8. irudia. Eisenia fetida zizareen pisu-galera (Hasierako pisua; \%) 28 egunez kutsatutako lurzorupean izan ostean. Desberdintasun esanguratsuak X batekin adierazi dira eskuineko matrizean.

\subsubsection{Jubenil kantitatea}

56 egun eta gero kontatutako jubenil kantitateak ez zuen desberdintasun esanguratsurik erakutsi talde esperimental ezberdinen artean (9. irudia).

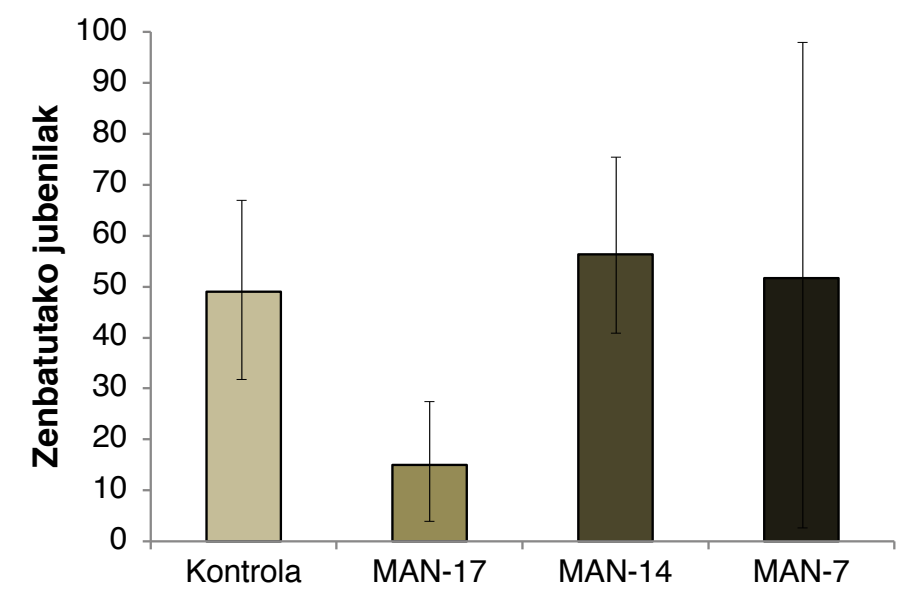

9. irudia. Esperimentuaren 56. egunean zenbatutako jubenil kantitatea, Eisenia fetida zizare helduak lurzoru kutsatupean 28 egunez izan ondoren.

MAN-14 taldea izan zen jubenil kantitate altuena erakutsi zuen tratamendua, batez beste 56 jubenil; MAN-7 eta kontrol-taldea izan ziren jarraian, 51 eta 49 banakorekin,hurrenez hurren. Aitzitik, jubenil kantitate baxuena MAN-17 lurzoruan zenbatu zen, 15 jubenil batez beste. 


\subsubsection{Oinordekotzaren pisu osoa}

Desberdintasun estatistikorik aurkitu ez arren, oinordekotzaren pisu osoaren balio altuenak MAN-7 eta MAN-14 taldeetan jaso ziren; bikoiztu egin zituzten MAN-17 taldean eta kontrol-taldeetan neurtutako batez besteko pisuak (MAN-7 lurzoruarekiko, 10. irudia).

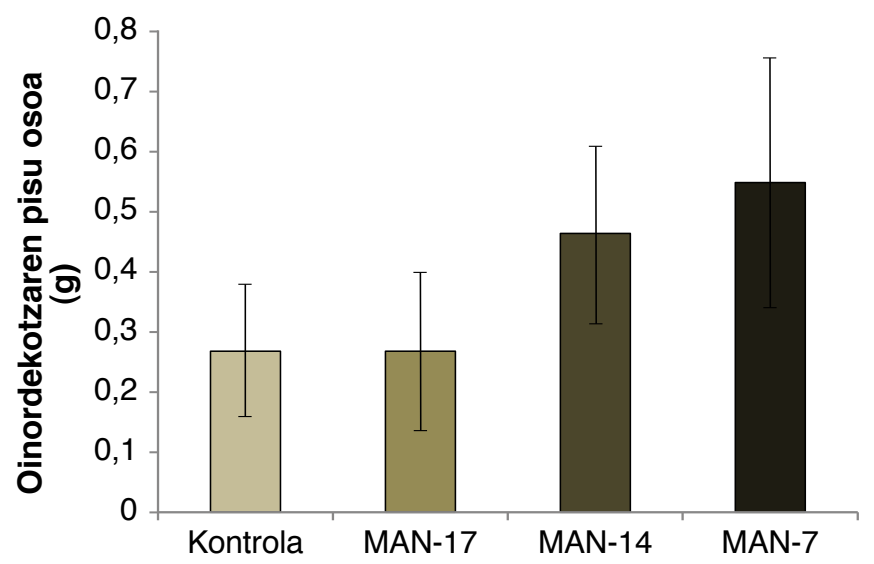

10. irudia. Esperimentuaren 56. egunean zenbatutako oinordekotzaren pisu osoa Eisenia fetida zizare helduak 28 egunez lurzoru kutsatupean izan ondoren.

\section{EZTABAIDA}

\subsection{Karakterizazio fisikokimikoak}

Lurzoruen propietateek zeharo baldintzatzen dituzte metalen eskuragarritasuna eta, hartara, toxikotasuna. Giltzarri diren ezaugarri horien artean daude buztin kantitatea, truke kationikorako ahalmena, $\mathrm{pH}$-a edota materia organiko (MO) kantitatea [22-25]. Epe laburreko toxikotasun-testetarako zein zizareen ugalketa-testetarako erabilitako lurren artean $\mathrm{pH}$ diferentziak ikusi ziren talde esperimentalen artean. Datu horiek, MO kantitateekin batera, talde ezberdinen arteko bioeskuragarritasun-desberdintasunak azalduko lituzkete [26]; izan ere, $\mathrm{pH}$ azidoetan $\mathrm{pH}$ neutro edo basikoetan baino handiagoa da lixibiatzeko ahalmena eta metalen bioeskuragarritasuna. Lurreko materialetara atxikitako metalak lurzoruetako materialen (katioak trukatzeko gaitasun altuak izaten dituzten buztin eta materia organikoak) antzekoagoak diren hidrogeno protoiekin trukatzen dira, eta, era horretan, askatu egiten dira. Era berean, MO eta kutsatzaileen arteko elkarketa indartsuak, estekatzaile organometalikoen bitartez gertatzen denak, kutsatzaileak lurrean finkatzen ditu, azken horiek fase urtarrera eta beste ingurune ba- 
Erik Urionabarrenetxea, Nerea Garcia-Velasco, Patxi Beraza, Marta Sánchez, Urtzi Izagirre, Beñat Zaldibar, Manu Soto

tzuetara migratzea ekidinez. Horrela, toxikotasuna aztertzerakoan, kontuan izan beharreko beste faktore bat da metalak lurzoruan igarotako denbora; izan ere, metalaren eskuragarritasuna jaitsi egiten da koprezipitatu horien eraketarekin batera [27]. Era horretan, kutsatuta dauden lurzoru zahartuetan metalen bioeskuragarritasuna zein toxikotasuna berriki kutsatutako lurzoruetan baino ahulagoa izatea espero da [28].

Fenomeno horiek ondo islatzen dira lixibiatuen analisi kimikoetan; horietan, MAN-14 taldea izan zen metalen kutsadura-maila altuenak erakutsi zituen taldea, printzipioz lurzoruan metal-maila altuenak zituen MAN-7 taldea gaindituz. Horren arrazoia MAN-14 taldeak erakutsitako materia organiko kantitate baxuagoa (\% 11 ML MAN-14an vs \% 19 ML MAN-7an) eta azidotasuna (6,28 MAN-14an vs 7,42 MAN-7an) izango lirateke.

\subsection{Lactuca sativa hazien ernetze- eta elongazio-testak}

Hirugarren eta zazpigarren egunetan zenbatutako ernetzeek ez zuten desberdintasun esanguratsurik erakutsi esposizio-talde ezberdinen artean. Hala ere, MAN-7 eta MAN-14 taldeetan ikusitako ernetze-ahalmenaren beherakada arina lixibiatuetan zenbatutako metal-kontzentrazioekiko alderantziz proportzionala zela ikusi zen. Test hori balioztatzeko asmoz, beronen sentikortasuna frogatu eta balioztatu zen kontrol positibo batekin; horretarako, Eusko Jaurlaritzak erabilera industrialerako ezarritako VIE-B balioetara esposatu ziren haziak.

Haziaren elongazio-testari dagokionez, emaitza berdintsuak lortu ziren esposizio-taldeen artean; lixibiatuetan dauden kutsatzaileak ez direla uraza kaltetzeko adina toxikoak frogatu zen. Ernetze-testean ez bezala, bi egunetako sustraien esposizioa ez zen nahikoa izan elongazioaren eta metalen arteko erlaziorik ikusteko. Talde kutsatuenetan ez zen inolako erantzunik sumatu, nahiz eta metal-metaketa altuenak eta lurzorukontzentrazio altuenak MAN-7 taldean ikusi. Erantzun gabezia horren arrazoia esposizio-kontzentrazio baxuetan legoke. Izan ere, lixibiatuetan neurtutako metal-kontzentrazioak urrun daude beste lan batzuetan urazei dagokienez argitaratutako LOEC kontzentrazioetatik: 2 ppb versus $14,4 \mathrm{ppm} \mathrm{Cd}, 12,4 \mathrm{ppb}$ versus $53,0 \mathrm{ppm} \mathrm{Pb}, 17,7 \mathrm{ppb}$ versus $6,9 \mathrm{ppm}$ $\mathrm{Ni}$ [29] eta 31,5 ppb versus 50,0 ppm Cr [30]. Berun-kontzentrazioek, uraza-sustrai guztietan, Europako (EU) 2015/1005 Arautegiak begetalentzat ezarritako 0,1 ppm-ko atalasea gainditu zuten. Kadmio-kontzentrazioek ere komisioaren 488/2014 Araudiak (elikagaietan gehienezko kadmio-kontzentrazioak ezartzen ditu) ezarritako legezko muga $(0,05 \mathrm{ppm})$ gainditu zuten. MAN-7 taldean, $\mathrm{Cr}$ eta Ni kontzentrazioek Brasilgo Legediak ( $\mathrm{Cr}$ eta $\mathrm{Ni}$-arentzat ez dago legezko atalaserik Espainiako edo Europako legedietan) gomendatutako atalaseak gainditu zituzten $(0,1 \mathrm{ppm} \mathrm{Cr}$ eta $5 \mathrm{ppm} \mathrm{Ni})$. 
Sustraietako metal-kontzentrazioetan, MAN-7-a izan zen metal gehien metatu zituen talde esperimentala; orokorrean, $\mathrm{Ni}$ eta $\mathrm{Pb}$ kontzentrazioak izan ziren gehien metatutako metal taldeak. Hala ere, esposizio lixibiatuei erreparatuz, MAN-7 taldea ez da metal-kontzentrazio altuenak dituena, ezta $\mathrm{Ni}$ eta $\mathrm{Pb}$ kutsatzaile kontzentratuenak dituena ere. Fenomeno hori etorkizuneko lanetan argitu beharreko absortzio-mekanismo konplexuen bidez bakarrik justifika daiteke.

\subsection{Eisenia fetida zizareen esposizioa kutsatutako lurzoruetan}

\subsubsection{Efektuak hiru egunen buruan}

Hiru eguneko esposizioaren ostean, zenbatutako pisu-galerak ez zuen patroi edo joera aipagarririk erakutsi talde ezberdinen artean. Baliteke esperimentazio-denbora laburregia erabili izana (testak, berez, 14 eguneko esposizioak gomendatzen ditu) kalte fisikorik edo pisu-galerarik antzeman ahal izateko. Izan ere, esperimentu horien bitartez, heriotza eragiteko kontzentrazioetatik beherago izaten diren erantzunak ebaluatzea bilatzen da; maila zelularrean gertatutako erantzunak ebaluatzea, adibidez. Modu horretan, esposatutako organismoen estres-maila aztertzea ahalbidetzen da, pisugalerak, heriotzak edo emendiorik gabeko efektuak gertatu baino lehen.

Shock elektriko bitartez eginiko erauzketan, beherakada nabarmena ikusi zen lurzoru kutsatupean izandako organismoetatik erauzitako zelula kantitatean; batez ere, MAN-14 eta MAN-7 taldeetan. Gainera, desberdintasun nabarmenak ikusi ziren kontrol-taldearen eta MAN-14 taldearen artean, non kontrolean baino \% 73 zelula gutxiago zenbatu baitziren. Aipatutako beherakada horiek, zelomozitoen erauzketaren eta lixibiatuen analisi kimikoen arteko joera negatiboarekin batera, zelulen beherakada zabortegiko kutsadurak eragindako erantzun zitotoxiko bat dela iradokitzen dute. Hipotesi hori zeharo indartu zen zelomozito-erauzketen emaitzen, kaltzeina-testen emaitzen eta ernetze-testen emaitzen artean aurkitutako joera antzekoekin.

Kaltzeinari dagokionez, kontrol-taldetik lurzoru kutsatuetara zihoan beherakada nabarmena ikusi zen; batez ere, MAN-7 eta MAN-14 taldeetan, hor ikusi baitziren kontrolarekiko desberdintasun nabarmenak. Talde horietako zizareen zelulek kaltzeina atxikitzeko ahalmen esanguratsuki baxuagoa erakutsi zuten kontrol-taldearekin alderatuz; hiru egunen ostean kalte zelularra zegoela baieztatu zen [31]. Zelulen tindagaiak atxikitzeko edo hartzeko ahalmenaren jaitsiera horrek eleozito/amebozito (zelomozito mota nagusiak) ratioaren alterazio batean izan zezakeen jatorria [32]. Izan ere, kaltzeina seinalean ikusitako jaitsiera hori metalen esposizioak induzitutako eleozito kantitatearen beherakada (amebozitoekin alderatuz) bategatik gerta zitekeen, eta amebozitoak izango ziren hildako eleozitoak fagozita- 
Erik Urionabarrenetxea, Nerea Garcia-Velasco, Patxi Beraza, Marta Sánchez, Urtzi Izagirre, Beñat Zaldibar, Manu Soto

tzen dituztenak [33]. Era berean, kaltzeina AM-ren bideragarritasun-entseguak baieztatu zuen hemozitometroarekin ikusitako joera.

Era horretan, eta pisu-galeran dosi-efektuaren erantzunik antzematen ez zen arren, zelula-mailan aplikaturiko entsegu ezberdinen bitartez, MAN-7 eta MAN-14 taldeetan hiru egunez esposatutako zizareek estres subletala pairatzen dutela frogatu zen.

\subsubsection{Efektuak 28 egunen buruan}

28 egun igarota, biomasa-galera txikiagoa ikusi zen kontrol-taldetik esposatutako taldeetara mugitzean. Pisu gehien kontrol-taldeak eta MAN-17 taldeak galdu zuten; pisu gutxien, aldiz, MAN-7 taldeak. Hala ere, talde guztiek galdu zuten hasierako pisuaren \% 20a baino gehiago; hots, talde guztiek pisu-galera kritikoa pairatu zuten [34].

Hiru egunen buruan ikusi zen bezala, ez zen antzeman esposizioarekin erlazionaturiko joerarik; pisu-galera txikienak kutsatuen zeuden taldeetan aurkitu ziren. Aldiz, hiru egunean lortutako emaitzetan ez bezala, MAN-7 eta MAN-14 taldeetan ikusitako pisu-galera lurzoruetan aurki daitekeen materia organikoaren bitartez azal daiteke. Izan ere, 1. taulan ikus daitekeen bezala, MAN-7 eta MAN-14 taldeek aurkezten dute materia organiko kantitate altuena (\% 19 eta \% 11, hurrenez hurren). Hori indartuz, kontrako joera argi bat ikusi izan zen 28 egunean neurtutako pisu-galeren eta lurzoruetako MO datuen artean. Modu horretan, kuantifikatutako pisu-galera lurzoruek daukaten MO kantitatearen araberakoa dela iradoki daiteke; eta ez, aldiz, kutsaduraren ondorio zuzena denik.

28 egunez esposatu ziren zizareen analisi kimikoetan, MAN-7 eta MAN-14 taldeek kontrol-taldeak eta MAN-17 taldeak baino metal-metaketa altuagoak erakutsi zituzten. Talde horietan kontzentrazio azpimarragarriak neurtu ziren, lurzoru kutsatuetara esposatuak izan zirela kontuan hartzen bada. Aipagarriak dira ehunetan metatutako Cd kontzentrazioak; horiek 18 eta 16 ppm-ra heltzen dira MAN-7 eta MAN-14 taldeetan. Kontzentrazio horiek, beste ornogabe askotan frogatu izan den bezala, nabarmenki igotzen dira esposizio-denborarekin batera [35]. Nabarmentzekoa da $\mathrm{Cr}$ eta $\mathrm{Cd}$ kontzentrazioen eta MO kantitateen arteko joera berdintsua ere, metal astun ioien sortzio arrazoi den metal-MO estekatzaileen eraketa iradokiz [36]. Gondek-ek eta bestek (2006) [22] argitaratutako lanak dio, besteak beste, araztegi-lokatzetako MOaren eta metalen arteko interakzioak aztertzerakoan, Cd-aren \% 25-59a eta Cr-aren \% 34-81a lurrean atxikita gelditzen dela MOarekin estekaturik. Hipotesi horrek indarra hartzen du 28 egunen buruan jasandako pisu-galeren eta metatutako $\mathrm{Cd}$ zein $\mathrm{Cr}$ kontzentrazioen alderantzizko proportzionaltasunarekin. Era horretan, metalekin estekatzaileak eratzen legokeen MOaren kontsumo altuago batekin azalduko litzateke MAN-7 eta MAN-14 taldeetako pisu-galera baxua. Hau 
da, metal astunekin kutsatutako MOa barneratzeagatik agertuko lirateke MAN-7 eta MAN-14 taldeetako metalen kontzentrazioak.

Bestalde, nabarmentzekoak dira zelomozitoen kontaketa eta $\mathrm{Cd}, \mathrm{Cr}$ edo $\mathrm{Ni}$ kontzentrazioen arteko erlazio negatiboak; baita germinazioaren eta $\mathrm{Pb}$-aren edo Ni-aren artekoak ere. Joera horiek aditzera ematen dute metatutako kontzentrazioen eta kuantifikatutako parametro/markatzaileen artean erlazio zuzen bat existitzen dela. Beste behin ere, behatutako erantzunak aipatutako kutsatzaileen esposizio eta metaketaren ondorio denaren hipotesia indartzen du.

\subsubsection{Ugalketa-testa}

56 egun eta gero, ez zen ikusi populazio-dinamiketan eragin zezakeen ugalketa-kalterik esposatutako taldeen artean; hau da, ez zen desberdintasun nabarmenik ikusi zizare jubenilen produkzioan.

Oinordekotzaren pisuetan, gorakada bat ikusi zen MAN-7 eta MAN-14 taldeetan, kontrolarekin eta MAN-17 taldearekin alderatuz gero; MAN-7 taldean, bereiziki, kontrolean eta MAN-17 taldean neurtutakoa bikoizteraino. Fenomeno hori MAN-7 (\% 19 MS) eta MAN-14 (\% 11 MS) taldeetako materia organiko kantitate altuen bitartez azal daiteke; horietan, arrautzak eklosionatu ziren momentutik, elikagai gehiago eskura zezaketen.

\section{ONDORIOAK}

Lan honetan gauzatutako lurzoruen osasun-ebaluazioan, emaitza kimikoak beste test toxikologiko batzuekin osatzeko beharra indartzen da, eta baita emaitzak osagarriak direla frogatzekoa ere. Bestalde, MO kantitatea eta $\mathrm{pH}$-a determinatzea kritikoa da; batetik, analisi ekotoxikologikoen interpretazio egokia egiteko, eta, bestetik, kutsatzaileen bioeskuragarritasunean aurki daitezkeen desberdintasunak azaltzeko.

Metal toxikoen presentziak maila altuko metaketak eragin zituen 28 egunen buruan 17-zabortegiko lurzoruetan jarritako zizareetan. Are gehiago, metaketa horiek emendatu egiten dira denboran zehar. Parametro zelularretan oinarritutako analisiek zabortegiko kutsatzaile anitzek eragindako efektu zitotoxikoa frogatu zuten. Erantzun zelular hori oso sentikorra eta goiztiarra da; organismo-mailako efektuak (biomasa galera, heriotza...) gertatu baino lehen, arriskua kuantifikatzeko tresna eraginkorrak direla bermatzen du. Era berean, efektu toxikoak antzemateko metodo baliagarria dela balioetsi da hainbat organismo erabiltzen dituzten entseguen konbinazioa.

Ondorioz, lan honetan frogatu da MAN-7 eta MAN-14 lurzoruetan dauden ornogabeak arriskuan egon daitezkeela; konponbide gisa, lurzoruen erremediatzea gomendatzen da. 
Erik Urionabarrenetxea, Nerea Garcia-Velasco, Patxi Beraza, Marta Sánchez, Urtzi Izagirre, Beñat Zaldibar, Manu Soto

\section{ESKER ONAK}

Esker onak eman nahi dizkiegu Gernikako Udalari, elkarrekin xedatutako hitzarmenak (2018/12/11) ahalbidetu baitu lan hau; Rafa Ensunza Gernika-Lumoko teknikari ohiari, bere jakintza eta gomendio ordainezinengatik; Biorem proiektuari (IHOBE, Ekoberrikuntza, 2017ko deialdia), lan hau finantzatzeagatik, eta ZBIT ikerkuntza-taldeari, emandako sostengu eta azpiegiturengatik.

\section{BIBLIOGRAFIA}

[1] GÓMEZ-SAGASTI, M.T., EPELDE, L., BARRUTIA, O. 2019. Fitorremediazioa lurzoru kutsatuen kudeaketa iraunkorrerako estrategia gisa. Ekaia, 35, 2019, 197-212.

[2] Organization for Economic Cooperation and Development OECD (1984) Earthworm, Acute Toxicity Tests-207. OECD guideline for testing of chemicals.

[3] International Organisation for Standardization (ISO), 2008. ISO 17512-1: Soil quality avoidance test for determining the quality of soils and effects of chemicals on behaviour. Part 1: Test with earthworms. Part 1: test with earthworms (Eisenia fetida and Eisenia andrei).

[4] SPURGEON, D.J., HOPKIN, S.P., JONES, D.T. 1994. Effects of cadmium, copper, lead and zinc on growth, reproduction and survival of the earthworm Eisenia fetida (Savigny): assessing the environmental impact of point-source metal contamination in terrestrial ecosystems. Environtal Pollution, 84, 123-130.

[5] LOPES ALVES, P.R., \& NOGUEIRA CARDOSO, E.J.B. 2016. Overview of the Standard Methods for Soil Ecotoxicology Testing. IntechOpen Limited. London.

[6] JOOSSE, E.N.G \& VERHOEF, S.G. 1983. Lead tolerance in Collembola. Pedobiologia, 25, 11-18.

[7] KOOIJMAN, S.A.L.M. \& METZ, J.A.J. 1984. On the dynamics of chemically stressed populations: the deduction of population consequences from effects on individuals. Ecotoxicology and Environmental Safety, 8, 254-74.

[8] MORIARTY, F. 1983. Ecotoxicology. The Study of Pollutants in Ecosystems. Academic Press, London, UK.

[9] OECD. 2004 guideline for the testing of chemicals 222. Earthworm reproduction test (Eisenia fetida/Eisenia andrei).

[10] CAJARAVILLE, M.P., BEBIANNO, M.J., BLASCO, J., PORTE, C., SARASQUETE, C., VIARENGO, A. 2000. The use of biomarkers to assess the impact of pollution in coastal environments of the Iberian Peninsula: a practical approach. Science of Total Environment, 247 (2-3), 295-311.

[11] MARIGÓMEZ, I., SOTO, M., KORTABITARTE, M. 1996. Tissue-level biomarkers and biological effect of mercury on sentinel slugs, Arion ater. Archives of Environmental Contamination and Toxicology, 31, 54-62. 
[12] CURIESES, S.P., GARCÍA-VELASCO, N., URIONABARRENETXEA, E., SÁENZ M.E., BILBAO, E., DI MARZIO, W.D., SOTO, M. 2017. Responses to silver nanoparticles and silver nitrate in a battery of biomarkers measured in coelomocytes and in target tissues of Eisenia fetida earthworms. Ecotoxicology and Environmental Safety, 141, 57-63.

[13] GARCIA-VELASCO, N., URIONABARRENETXEA, E., SOTO, M., ZALDIBAR, B. 2020. Sedimentuen toxikotasunaren azterketa integrala ekologikoki esangarriak diren espezieak erabiliz. Ekaia, Ale berezia, 2020, 221-231. https://doi.org/10.1387/ekaia.21058.

[14] ASENSIO, V., RODRÍGUEZ-RUIZ, A., GARMENDIA, L., ANDRE, J., KILLE, P., MORGAN, A.J, SOTO, M., MARIGÓMEZ I. 2013. Towards an integrative soil health assessment strategy: A three tier (integrative biomarker response) approach with Eisenia fetida applied to soils subjected to chronic metal pollution. Science of Total Environment, 442, 344-365.

[15] IRIZAR, A., DUARTE, D., GUILHERMINO, L., MARIGÓMEZ, I., SOTO, M., 2014a. Optimization of NRU assay in primary cultures of Eisenia fetida for metal toxicity assessment. Ecotoxicology, 23 (7), 1326-35.

[16] IRIZAR, A., IZAGIRRE, U., DIAZ DE CERIO, O., MARIGÓMEZ, I., SOTO, M.. 2014b. Zonation in the digestive tract of Eisenia fetida: implications in biomarker measurements for toxicity assessment. Comparative Biochemistry and Physiology Part $C, \mathbf{1 6 0}, 42-53$.

[17] IRIZAR, A., RODRIGUEZ, M.P., IZQUIERDO, A., CANCIO, I., MARIGÓMEZ, I., SOTO, M. 2015. Effects of Soil Organic Matter Content on Cadmium Toxicity in Eisenia Fetida: Implications for the Use of Biomarkers and Standard Toxicity Tests. Archives of Environmental Contamination and Toxicology, 68, 181-192.

[18] OECD. 2003. (Organisation for Economic Co-operation and Development). Guideline for the testing of chemicals. Proposal for updating guideline 208. Terrestrial Plant Test: 208: Seedling Emergence and Seedling Growth Test.

[19] EPA (United States Environmental Protection Agency). 1996. Ecological effects test guidelines. Seed germination/root elongation toxicity test. OPPTS 850.4200 .

[20] ADAMO, P., LAVAZZO, P., ALBANESE, S,. AGRELli, D., DE VIVO, B., LIMA, A. 2014. Bioavailability and soil-to-plant transfer factors as indicators of potentially toxic element contamination in agricultural soils. Science of Total Environment, 500-501, 11-22.

[21] IN C.K. 2013. Joint effects of heavy metal binary mixtures on seed germination, root and shoot growth, bacterial bioluminescence, and gene mutation. Journal of Environtal Science, 25 (5), 889-894.

[22] GONDEK, K., KOPEĆ, M. 2006. Heavy metal binding by organic substance in sewage sludge of various origin. EJPAU. 9. issue 3.

[23] LEDUC, F., WHALEN, J.K., SUNAHARA, G.I. 2007. Growth and reproduction of the earthworm Eisenia fetida after exposure to leachate from wood preservatives. Ecotoxicology and Environmental Safety, 69, 219-226. 
Erik Urionabarrenetxea, Nerea Garcia-Velasco, Patxi Beraza, Marta Sánchez, Urtzi Izagirre, Beñat Zaldibar, Manu Soto

[24] SMIT, C.E., VAN GESTEL, C.A.M. 1998. Effects of soil type, pre percolation, and ageing on bioaccumulation and toxicity of zinc for the springtail Folsomia candida. Environtal Toxicology and Chemistry, 17, 1132-1141.

[25] SPURGEON, D.J., HOPKIN, S.P. 1995. Extrapolation of the laboratory- based OECD earthworm toxicity test to metal-contaminated field sites. Ecotoxicology, 4, 190-205.

[26] VISIOLI, G., MENTA, C., GARDI, C., DELIA CONTI, F. 2013. Metal toxicity and biodiversity in serpentine soils: Application of bioassay tests and microarthropod index. Chemosphere, 90, 1267-1273.

[27] MARTINEZ, C.E., MCBRIDE, M.B. 2001. Cd, Cu, Pb and Zn coprecipitates in Fe oxide formed at different $\mathrm{pH}$ : aging effects on metal solubility and extractability by citrate. Environmental Toxicology and Chemistry, 20, 122-126.

[28] SMOLDERS, E., OORTS, K., VAN SPRANG, P., SCHOETERS, I., JANSSEN, C.R., MCGRATH, S.P., MCLAUGHLIN, M.J. 2009. Toxicity of trace metals in soils affected by soil type and aging after contamination: using calibrated bioavailability models to set ecological soil standards. Environmental Toxicology and Chemistry, 28, 1633-1642.

[29] DI SALVATORE, M., CARAFA, A.M., CARRATÙ, G. 2008. Assessment of heavy metals phytotoxicity using seed germination and root elongation tests: A comparison of two growth substrates. Chemosphere, 73, 1461-1464.

[30] HOU J., LIU G.N., XUE W., FU W.J., LIANG B.C., LIU X.H. 2013. Seed germination, root elongation, root-tip mitosis, and micronucleus Induction of five crop plants exposed to chromium in fluvo-aquic soil. Environmental Toxicology and Chemistry, 33 (3), 671-676.

[31] PLYTYCZ, B.,KLIMEK, M., HOMA,J., TYLKO, G.,KOLACZKOWSKA,E., 2007. Flow cytometric measurement of neutral red accumulation in earthworm coelomocytes: Novel assay for studies on heavy metal exposure. European Journal of Soil Biology. 43 (1). S116-S120

[32] PLYTYCZ, B., LIS-MOLENDA, U., CYGAL, M., KIELBASA, E., GREBOSZ, A., DUCHNOWSKI, M., ANDRE, J., MORGAN, A.J. 2009. Riboflavin content of coelomocytes in earthworm (Dendrodrilus rubidus) field populations as a molecular biomarker of soil metal pollution. Environtal Pollution, 157, 3042-3050.

[33] IRIZAR, A. 2013. Soil health assessment through in vitro assays with primary cultures of coelomocytes of Eisenia fetida. Ph D Thesis, Departamento de Zoología y Biología Animal. Euskal Herriko Unibertsitatea.

[34] GARCIA-VELASCO, N., PEÑA-CEARRA,A., BILBAO, E., ZALDIBAR, B., SOTO, M. 2017. Integrative assessment of the effects produced by Ag nanoparticles at different levels of biological complexity in Eisenia fetida mantained in two standard soils (OECD and LUFA 2.3). Chemosphere, 181, 747-758.

[35] CALLAHAN, M.A., SLIMAK, M.W., GABEL N.W. 1979. Water-Related Enviromental Fate of 129 Priority pollutants. Vol. 1. Introduction and Technical Background, Metals and Inorganics, Pesticides and PCBs. Report to U.S. Evi- 
romental Protection Agency, Office of Water Planning and Standards, Washington, D.C., by Versar Incorporated, Springfield, VA. EPA/ 440/4-79/029a.

[36] GONDEK, K., BARAN, A., KOPEC, M. 2014.The effect of low-temperature transformation of mixtures of sewage sludge and plant material son content, leachability and toxicity of heavy metals. Chemosphere, 117, 33-39. 
